NASA Technical Memorandum 100224

\title{
Transply Crack Density Detection by Acousto-Ultrasonics
}

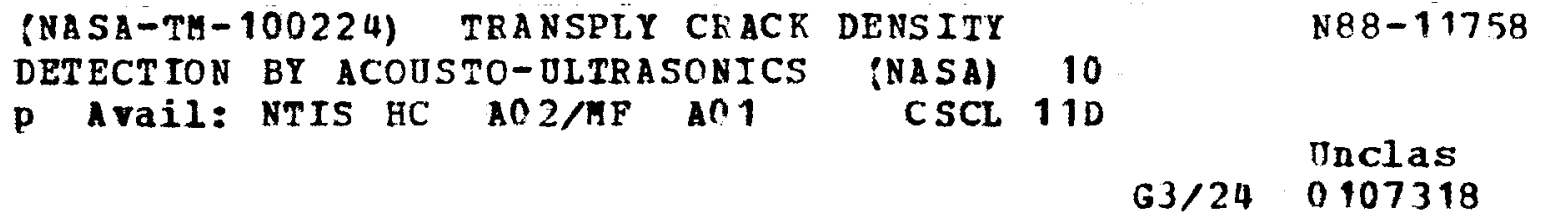

John H. Hemann

Cleveland State University

Cleveland, Ohio

Kenneth J. Bowles and Harold Kautz

Lewis Research Center

Cleveland, Ohio

and

Paul Cavano

Cleveland State University

Cleveland, Ohio

Prepared for

Acousto-Ultrasonics: Theory and Application sponsored by NASA Lewis Research Center

Blacksburg, Virginia, July 12-15, 1987 
TRANSPLY CRACK DENSITY DETECTION BY ACOUSTO-ULTRASONICS

\author{
John H. Hemann \\ Cleveland State University \\ Cleveland, Ohio 44115 \\ Kenneth J. Bowles and Harold Kautz \\ National Aeronautics and Space Administration \\ Lewis Research Center \\ Cleveland, Ohio 44135 \\ and \\ Paul Cavano \\ Cleveland State University \\ Cleveland, Ohio 44115
}

The acousto-ultrasonic method was applied to a PMR-15 8-harness, satin Celion 3000 fabric composite to determine the extent of transply cracking. A six-ply 0/90 laminate was also subjected to mechanical loading, which induced transply cracking. The stress wave factor (SWF) is defined as the energy contained in the received signal from a 2.25-MHz center frequency transducer. The correlation of the SWF with transply crack density is shown.

\title{
INTRODUCTION
}

The use of advanced composite materials, particularly for aerospace use, requires dimensional stability and absence of cracks. The presence of cracks reduces mechanical characteristics and exposes the fibers and interfaces to environmental (moisture) effects. Graphite/PMR polyimide composites are candidate materials to replace metals in moderate-high-temperature zones (up to $\left.316^{\circ} \mathrm{C}\right)$ in jet engines. These types of applications will introduce thermal cycling, which in turn will produce transply cracking unless improved materials are developed. Because these transply cracks are very undesirable, nondestructive evaluation (NDE) techniques are needed to detect the presence of transply cracks. This paper will demonstrate that acousto-ultrasonics (refs. 1 and 2) can be used to detect transply cracks in graphite/PMR cross-ply and woven fabric laminates.

Adams et al. (ref. 3) have demonstrated experimentally that thermally induced transply cracking occurs in graphite epoxy cross-ply laminates for varlous laminate configurations. Ishikawa and Chou (ref. 4) discuss the existence of transply cracks in woven fabric composites. It has been shown that transply cracks do exist, both in cross-ply and woven fabric laminates, and can be created by either mechanical loading or thermal cycling.

This paper will show that the acousto-ultrasonic stress wave factor (SWF) does correlate with transply crack density. The cracks studied were created by room temperature tensile loading of the material. 


\section{MATERIALS AND METHODS}

Two different PMR-15 matrix material systems were employed in this investigation, one a woven graphite fabric reinforced system and the other a crossply layup made of unidirectional graphite tape. All laminates were prepared and die molded as described in reference 5 . None of the panels was postcured. All of the laminates had a nominal fiber fraction of 60 vol \% and a void content of less than 1 percent as determined by matrix digestion and density measurements.

The woven fabric laminates were prepared from prepreg obtained from the Ferro Corporation, Culver City, California. The material is identified by Ferro as CPI 2237/CEL 3K, 8 HS. This designates a PMR-15 polyimide on an eightharness satin weave fabric of Celion carbon fiber. Both panels molded were six plies thick, and all plies were warp oriented. The panels were $15 \mathrm{~cm}$ wide by $30 \mathrm{~cm}$ long (warp direction) by $0.21 \mathrm{~cm}$ thick ( 6 by 12 by $0.084 \mathrm{in.}$ ).

After molding, the panels were determined to be of acceptable quality (void free) by through-transmission ultrasonic (C-scan) inspection. The panels were then cut into specimens $30 \mathrm{~cm}$ long $(12 \mathrm{in.})$ and $1.3 \mathrm{~cm}$ wide $(0.5 \mathrm{in}$.$) and$ fitted with laminated fiberglass end tabs. Optical microscopy was used to examine the cut edges for voids. None were found. These straight-sided tensile specimens were then initially nondestructively inspected by using the acousto-ultrasonic method.

The cross-ply laminate used a modified PMR-15 resin with a Celion C-6000 carbon fiber tow, prepregged at the NASA Lewis Research Center. The resin modification consisted of substituting pyromellitic dianhydride for the benzophenone dianhydride ordinarily used in PMR-15. The construction was 14 plies in a symmetrical $\left((90 / 0)_{3} 90\right)^{5}$ layup. The panels were $15 \mathrm{~cm}$ wide by $20 \mathrm{~cm}$ long $\left(0^{\circ}\right.$ direction) by $0.26 \mathrm{~cm}$ thick ( 6 by 8 by $0.104 \mathrm{in.}$ ). The panels were also C-scanned and then cut into $20-$ by $1.3-\mathrm{cm}$ tensile specimens. Tab bonding and initial acousto-ultrasonic readings were done as previously described for the woven fabric laminates.

Acousto-ultrasonic measurements were made by using a pair of $2.25-\mathrm{MHz}$ center frequency transducers with a $1-\mathrm{MHz}$ band width. A schematic diagram of the acousto-ultrasonic systems, transducers, and specimen is shown in figure 1. The system is described in detail in reference 2. Ultrasonic coupling was achieved by using a pair of 0.30 - by $1.27-\mathrm{cm}(0.125-$ by $0.5-i n$.) silicon rubber pads. The transducer center line separation was $3.8 \mathrm{~cm}(1.5 \mathrm{in}$.), with $1.9 \mathrm{~cm}$ ( 0.75 in.) overlapping measurements done on each side of the specimens.

Crack density values reported represent an indication of cracks present, rather than an actual count of all cracks. The crack density values were assigned by counting the cracks that were microscopically apparent (200X) in the center two plies of the laminate. This was done by examining the edge of the laminate under the microscope and counting the cracks in each 1.9-cm (0.75-in.) length as established by the acousto-ultrasonic wave. Figure 2 shows photomicrographs of polished sections of specimens showing these transply cracks in the cross-ply laminate and in the woven fabric laminate.

The tabbed specimens were axially loaded in a tensile test machine at the loading rate of $1.3 \mathrm{~mm} / \mathrm{min}(0.05 \mathrm{in.} / \mathrm{min})$, held for $5 \mathrm{~min}$ at the preassigned load level, unloaded, and microscopically examined for the presence of cracks. 
For the woven fabric laminate the loads were applied in the warp direction. One of the fabric laminate specimens was strain gaged and loaded to produce a stress-strain curve. The stress-strain curve was linear to failure: the warp stiffness was $69.6 \mathrm{GPa}\left(10.1 \times 10^{6} \mathrm{psi}\right)$, the failure stress was $965 \mathrm{MPa}$ (140 ksi), and the fallure strain was 1.4 percent. By using the upper limit on the failure strain from the stress-strain test, a series of specimens were strained to various prescribed levels to provide a range of crack densities. Then the specimens were examined microscopically and inspected acoustoultrasonically. The threshold strain to cause transply cracking in the woven fabric laminate was measured to be 0.75 percent.

For the cross-ply laminate the load was only applied in the longitudinal direction of the $0^{\circ}$ plies. One of the specimens was strain gaged and used to obtain a strain-stress curve. The stress-strain curve was linear to failure: the longitudinal stiffness was $52 \mathrm{GPa}\left(7.5 \times 10^{6} \mathrm{psi}\right)$, the failure stress was $900 \mathrm{MPa}$ (130.6 ksi), and the failure strain was 1.66 percent. For the crossply laminate a single specimen was selected for repetitive, sequentially increased loading, with microscopic crack examination and acousto-ultrasonic scanning at each load level. The threshold strain to cause transply cracking in the cross-ply laminate was measured to be 0.65 percent.

\section{RESULTS}

Typical time and frequency domain digitized signals are shown in figure $3(a)$ for the cross-ply laminate. The woven fabric laminate (fig. $3(b)$ ) is discussed later in this section. The SWF factor used in this paper is the root mean square (RMS) voltage over a specified time period and frequency band. At each crack density level as produced by a given load, SWF measurements were taken at five positions at equal intervals along the length on both sides of the specimen and averaged. This may be reported over the entire time and frequency domain, or, as in this case, the signal may be partitioned in time and frequency. Time was partitioned in 5- $\mu$ sec intervals, and frequency was partitioned in 1.285-MHz bands. The SWF measurements were taken at seven different crack densities.

By using a linear least-squares fit to the data, correlations of SWF to crack density were determined for all times and frequencies, for each $1.285-\mathrm{MHz}$ frequency band, for each 5- $\mu$ sec time interval, and for simultaneous time and frequency partitioning. Table $I$ is a time and frequency partition correlation table. Figure $4(a)$ shows the SWF and crack density data and the fit of a linear curve to the data for the 10- to 15- $\mu \mathrm{sec}$ time interval and the 0 - to 1.285-MHz frequency band; these data show the best correlation, -0.835 , of any partition. The SWF error is the standard deviation of data averaged in each point. Crack density is \pm 0.52 for all data.

The decrease of the SWF with crack density is expected because the cracks formed are barriers to the propagation of stress and cause the decrease in amplitude of the stress wave. The good correlation occurring at the lowest frequencies and shortest times is also expected because the signal is strongest in these regimes. These materials are known to be very attenuating. Thus, at low frequencies the signal is distinct and large; at higher frequencies it is small and lost in noise. At long times the signal reaching the receiving transducer is a complex superposition of many Lamb modes of different speeds and types which will destroy correlation. At the shortest times only the 
fastest modes (or mode) are seen at the receiving transducer and thus constructive superposition occurs, but decreases in amplitude with increasing crack density.

Typical time and frequency domain signals are shown in figure 3(b) for the woven fabric laminate. Table II shows the time and frequency partition correlation data. Figure $4(\mathrm{~b})$ shows the SWF and crack density data and the fit of a linear curve to the data for the 10- to 15- $\mu \mathrm{sec}$ time interval and for the 0 - to 1.285-MHz frequency band. SWF measurements were taken at seven positions at equal intervals along the length on each side of the specimens and averaged. The correlation was once again better at the shorter times, but generally good at all times and frequencies.

The SWF again decreased with increasing crack density, as expected, indicating that cracks cause attenuation of the stress wave. The woven fabric had cracks in all six plies, whereas the cross-ply was only transply cracked in the $90^{\circ}$ plies. It is clear from the data that the woven fabric is a less attenuating material than the cross-ply fabric at low crack densities, but at higher crack density levels, near laminate failure, the stress wave factors in both materials were nearly equal.

\section{CONCLUSIONS}

The acousto-ultrasonic method holds promise as a method to assess crack density. It is very clear from the data that the energy transmitted (SWF) decreases with increasing crack density. Thus, the SWF may be a practical measure and predictor of crack density in laminated composite materials.

There also exists evidence that time and frequency partitioning will be useful in producing good correlations between SWF and crack density.

\section{REFERENCES}

1. Vary, A.: Acousto-Ultrasonic Characterization of Fiber Reinforced Composites. NASA TM-82651, 1981.

2. Kautz, H.E.: Acousto-Ultrasonic Verification of the Strength of Filament Wound Composite Material. NASA TM-88827, 1986.

3. Adams, D.S.; Bowles, D.E.; and Herakovich, C.T.: Thermally Induced Transverse Cracking in Graphite-Epoxy Cross-ply Laminates. J. Reinforced Plastics Compos., vol. 5, no. 3, July 1986, pp. 152-169.

4. Ishikawa, T.; and Chou, T.W.: In-Plane Thermal Expansion and Thermal Bending Coefficients of Fabric Composites. J. Compos. Mater., vol. 17, no. 2, Mar. 1983, pp. 92-104.

5. Vannuci, R.D.: PMR-15 Polyimide Modifications for Improved Prepreg Tack," The Plastics ABC's: Polymer Alloys, Blends and Composites, 1982 National Technical Conference, Society of Plastics Engineers, Brookfield Center, CT, 1982, pp. 131-133. (NASA TM-82951.) 
TABLE I. - CORRELATION COEFFICIENTS FOR STRESS WAVE FACTOR (SWF) AS FUNCTION OF CRACK DENSITY IN TIME AND FREQUENCY PARTITIONS

FOR CROSS-PLY LAMINATE

\begin{tabular}{|c|c|c|c|c|c|}
\hline \multirow{2}{*}{$\begin{array}{c}\text { Time } \\
\text { interval, } \\
\text { } \text { sec }\end{array}$} & \multicolumn{5}{|c|}{ Frequency band, $\mathrm{MHz}$} \\
\hline & 0 to 1.285 & 1.285 to 2.57 & 2.57 to 3.855 & 3.855 to 5.14 & $\begin{array}{l}5.14 \text { to } \\
\text { total spectrum }\end{array}$ \\
\hline $\begin{array}{l}0 \text { to } 5 \\
5 \text { to } 10 \\
10 \text { to } 15 \\
15 \text { to } 20 \\
20 \text { to } 25 \\
25 \text { to } 30 \\
30 \text { to } 35 \\
35 \text { to } 40 \\
40 \text { to } 45 \\
45 \text { to } 50 \\
50 \text { to } \\
\text { total time }\end{array}$ & $\begin{array}{l}0.579 \\
-.598 \\
-.835 \\
.315 \\
.474 \\
-.081 \\
.645 \\
.368 \\
.205 \\
.57 \\
.481\end{array}$ & $\begin{array}{r}-0.057 \\
-.505 \\
-.523 \\
.373 \\
.379 \\
-.362 \\
-.282 \\
-.342 \\
-.295 \\
.049 \\
-.576\end{array}$ & $\begin{array}{l}0.449 \\
-.301 \\
-.494 \\
.523 \\
.403 \\
-.25 \\
-.105 \\
-.02 \\
-.101 \\
.339 \\
.299\end{array}$ & $\begin{array}{l}0.173 \\
-.62 \\
-.5 \\
.405 \\
.342 \\
-.397 \\
-.397 \\
-.353 \\
-.309 \\
.227 \\
.187\end{array}$ & $\begin{array}{l}0.696 \\
-.176 \\
-.812 \\
.57 \\
.487 \\
.407 \\
.602 \\
.448 \\
.364 \\
.622 \\
.465\end{array}$ \\
\hline
\end{tabular}

TABLE II. - CORRELATION COEFFICIENTS FOR STRESS WAVE FACTOR (SWF) AS FUNCTION OF CRACK DENSITY IN TIME AND FREQUENCY PARTITIONS FOR WOVEN FABRIC LAMINATE

\begin{tabular}{|c|c|c|c|c|c|}
\hline \multirow{2}{*}{$\begin{array}{c}\text { Time } \\
\text { interva1, } \\
\mu s e c\end{array}$} & \multicolumn{5}{|c|}{ Frequency band, MHz } \\
\cline { 2 - 6 } & 0 to 1.285 & 1.285 to 2.57 & 2.57 to 3.855 & 3.855 to 5.14 & $\begin{array}{c}5.14 \text { to } \\
\text { total } \\
\text { spectrum }\end{array}$ \\
\hline 0 to 5 & 0.374 & 0.794 & 0.738 & 0.069 & 0.307 \\
5 to 10 & -.924 & -.863 & -.858 & -.868 & -.811 \\
10 to 15 & -.863 & -.859 & -.794 & -.695 & -.821 \\
15 to 20 & -.899 & -.882 & -.862 & -.826 & -.894 \\
20 to 25 & 0 & -.57 & -.136 & -.533 & -.089 \\
25 to 30 & -.808 & -.627 & -.456 & -.522 & -.734 \\
30 to 35 & -.543 & -.285 & -.239 & -.578 & -.764 \\
35 to 40 & .333 & -.534 & -.668 & -.838 & -.539 \\
40 to 45 & -.375 & -.522 & -.498 & -.767 & -.673 \\
45 to 50 & -.669 & -.57 & -.749 & & -.852 \\
50 to & -.848 & -.862 & -.825 & & \\
total time & & & & & \\
\hline
\end{tabular}



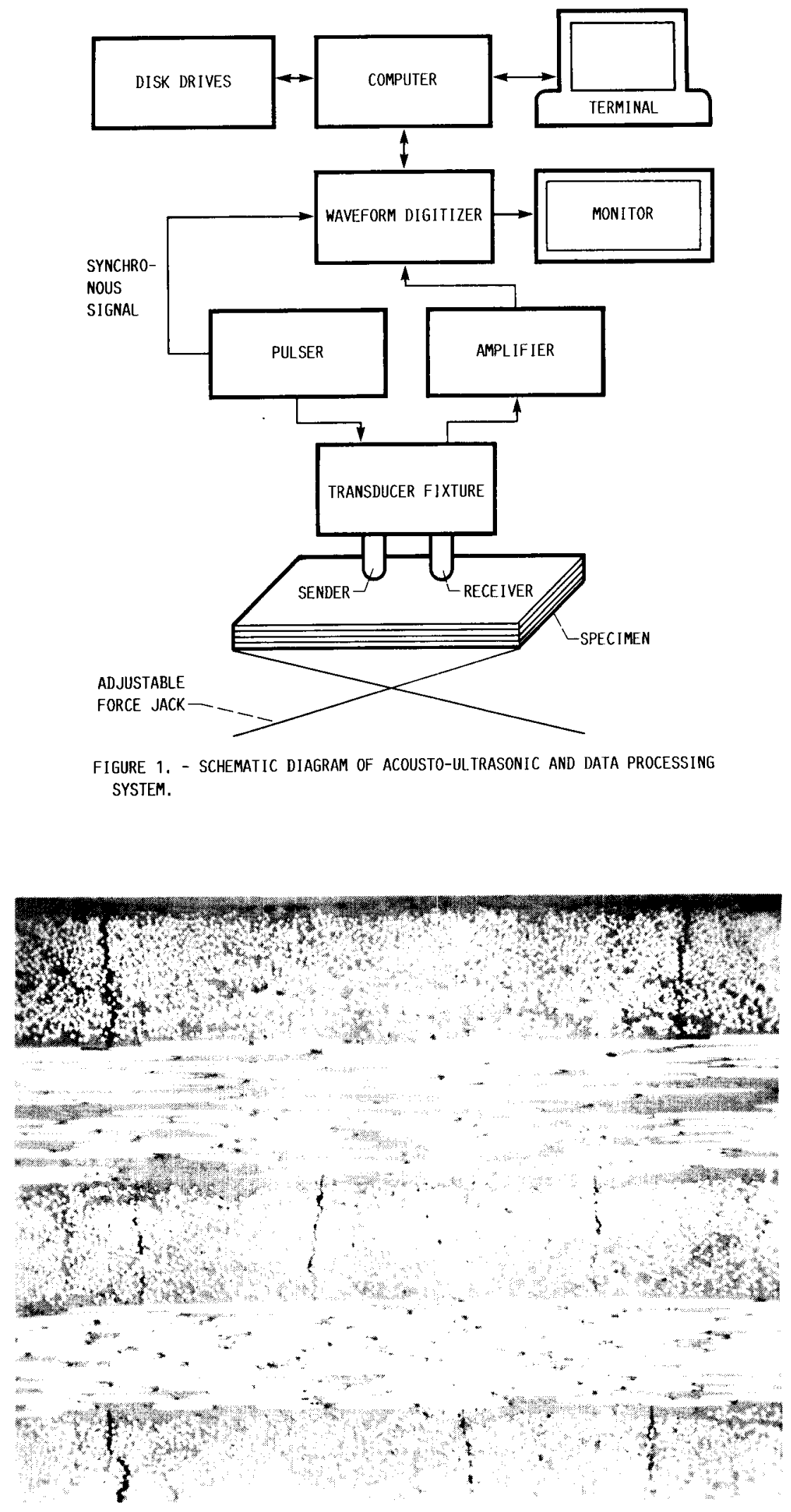

(A) CROSS-PLY LAMINATE.

FIGURE 2. - PHOTOMICROGRAPHS OF CROSS-PLY AND WOVEN FABRIC LAMINATES SHOWING TRANSPLY CRACKS (50X). 


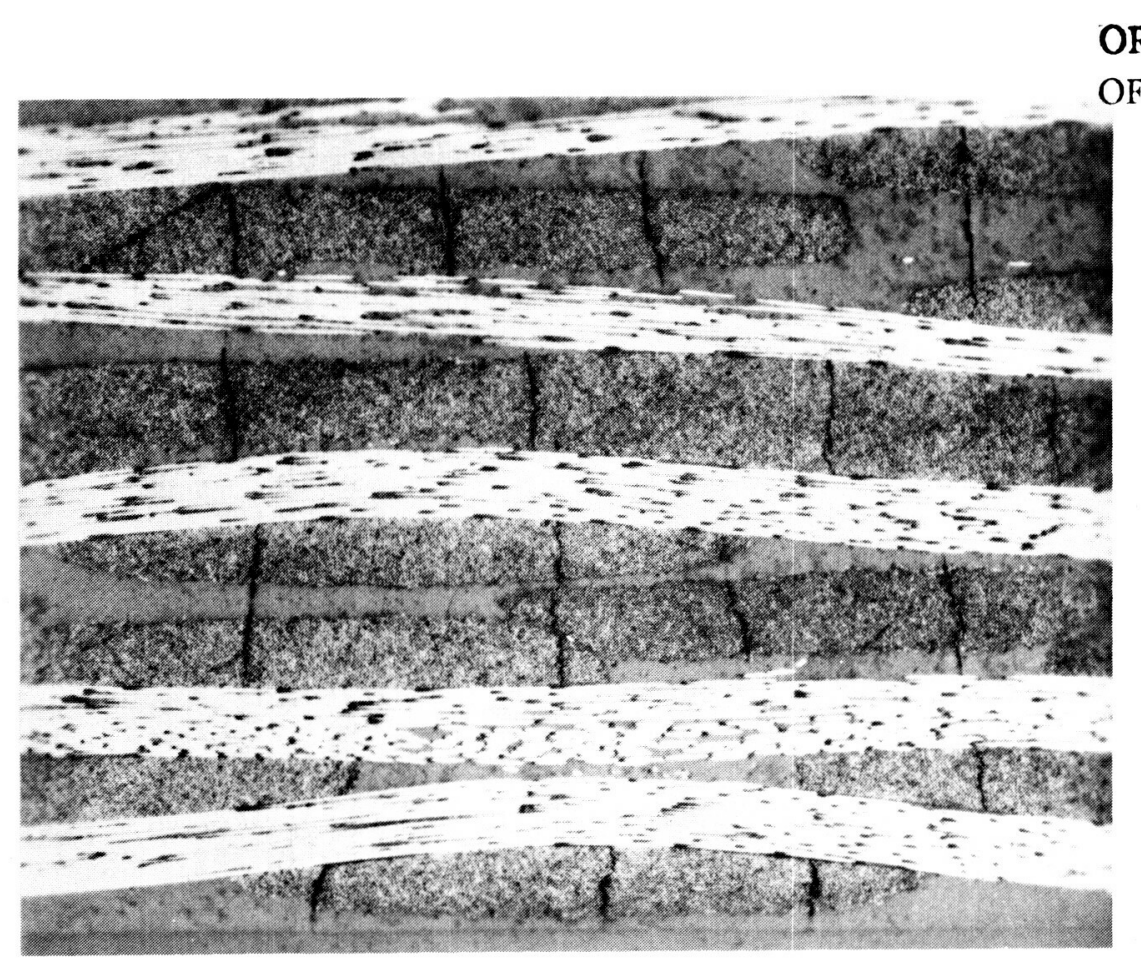

ORIGINAL PAGE IS

(B) WOVEN FABRIC LAMINATE.

FIGURE 2. - CONCLUDED.
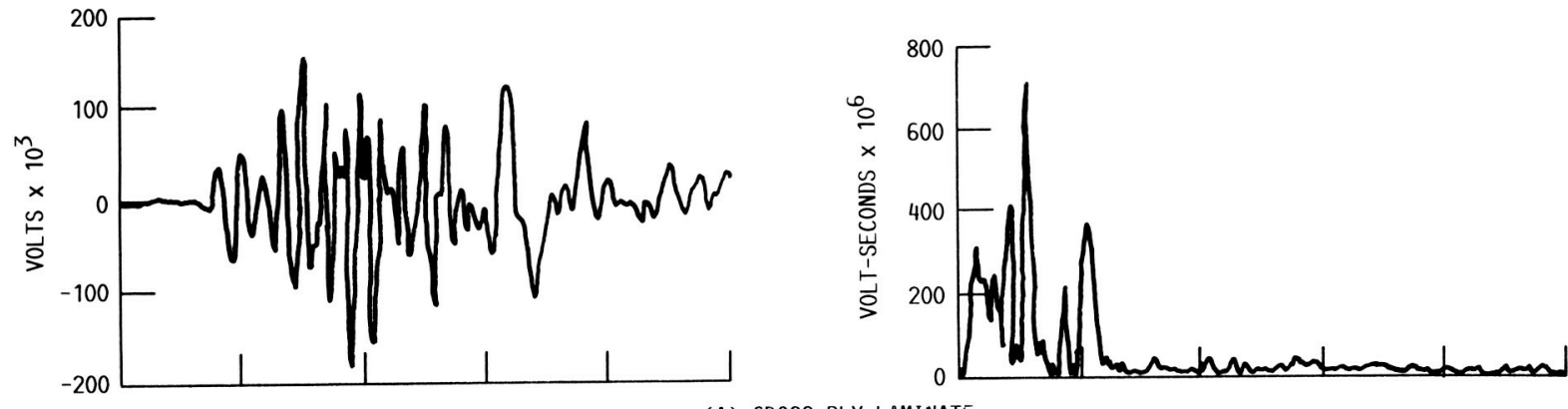

(A) CROSS-PLY LAMINATE.
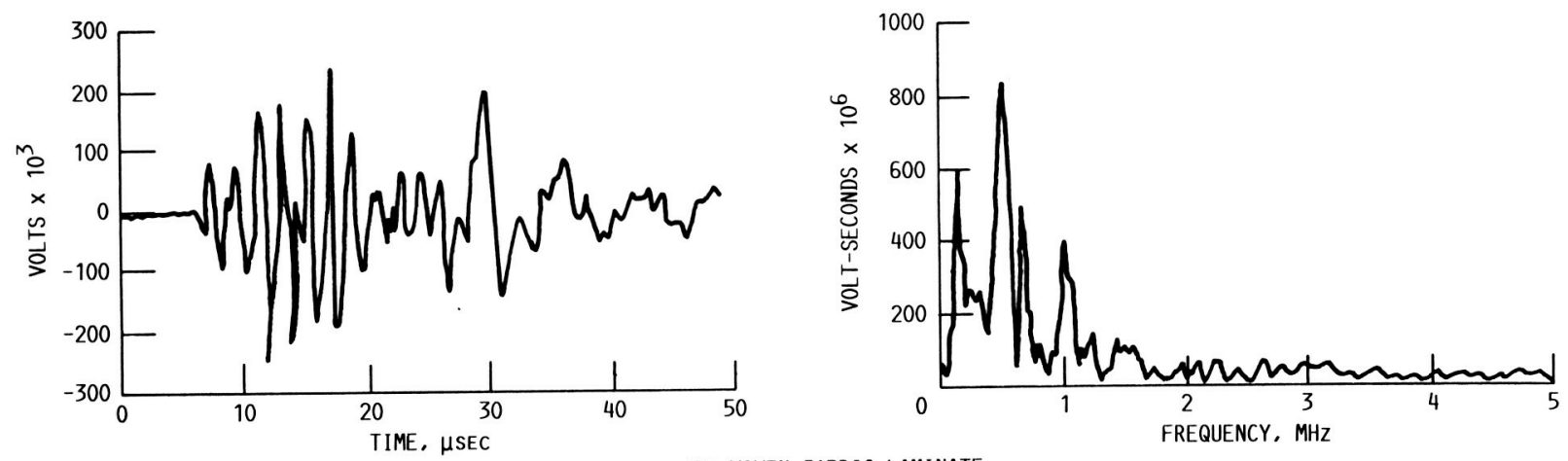

(B) WOVEN FABRIC LAMINATE.

FIGURE 3. - TYPICAL DIGITIZED TIME DOMAIN AND FREQUENCY SPECTRUM OF CROSS-PLY AND WOVEN FABRIC LAMINATES. 


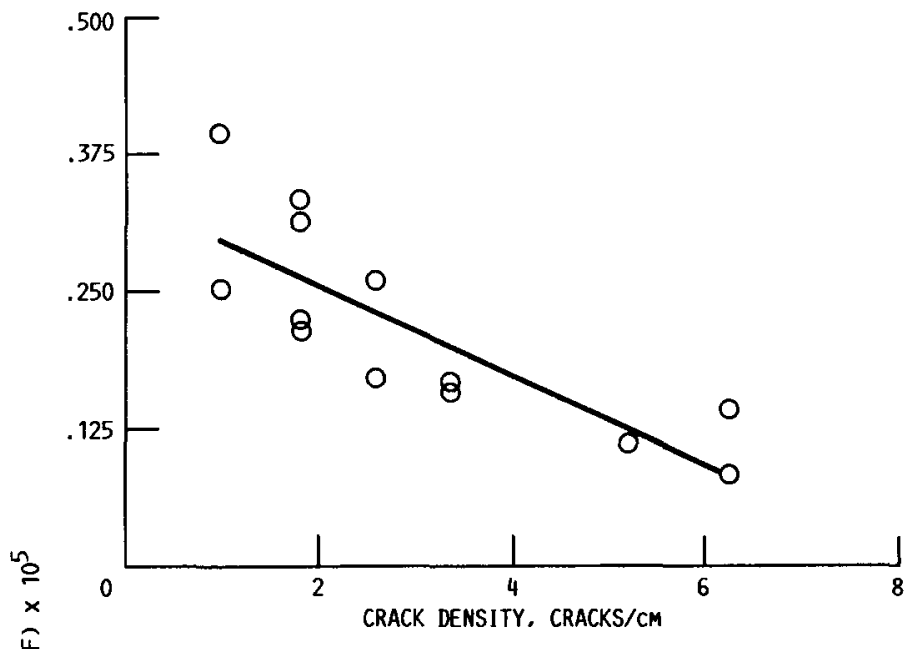

$\begin{array}{crc}\begin{array}{c}\text { STRESS WAVE } \\ \text { FACTOR } \\ \text { (SWF) }\end{array} & \begin{array}{r}\text { SWF } \\ \text { ERROR, } \\ \text { PERCENT }\end{array} & \begin{array}{c}\text { CRACK } \\ \text { DENSITY, } \\ \text { CRACKS/CM }\end{array} \\ 3.96749 \times 10^{-6} & \pm 35.66 & 1.05 \\ 2.55538 \times 10^{-6} & \pm 16.47 & 1.05 \\ 3.17030 \times 10^{-6} & \pm 1.65 & 1.84 \\ 3.35806 \times 10^{-6} & \pm 14.38 & 1.84 \\ 2.27259 \times 10^{-6} & \pm 14.38 & 1.84 \\ 2.17156 \times 10^{-6} & \pm 6.98 & 1.84 \\ 2.62482 \times 10^{-6} & \pm 4.34 & 2.62 \\ 1.73025 \times 10^{-6} & \pm 18.53 & 2.62 \\ 1.69679 \times 10^{-6} & \pm 22.40 & 3.41 \\ 1.58215 \times 10^{-6} & \pm 29.20 & 3.41 \\ 1.11332 \times 10^{-6} & \pm 15.28 & 5.25 \\ 1.08006 \times 10^{-6} & \pm 31.42 & 5.25 \\ 8.35827 \times 10^{-7} & \pm 18.47 & 6.30 \\ 1.42240 \times 10^{-6} & \pm 1.42 & 6.30 \\ \text { a CRACK DENSITY } & \text { IS } \pm 0.52 \text { FOR ALL DATA. }\end{array}$

(A) CROSS-PLY LAMINATE. LEAST-SQUARES COEFFICIENT R, -0.835 : INTERCEPT, $3.45121 \times 10^{-6}$; SLOPE, $-4.19899 \times 10^{-7}$.

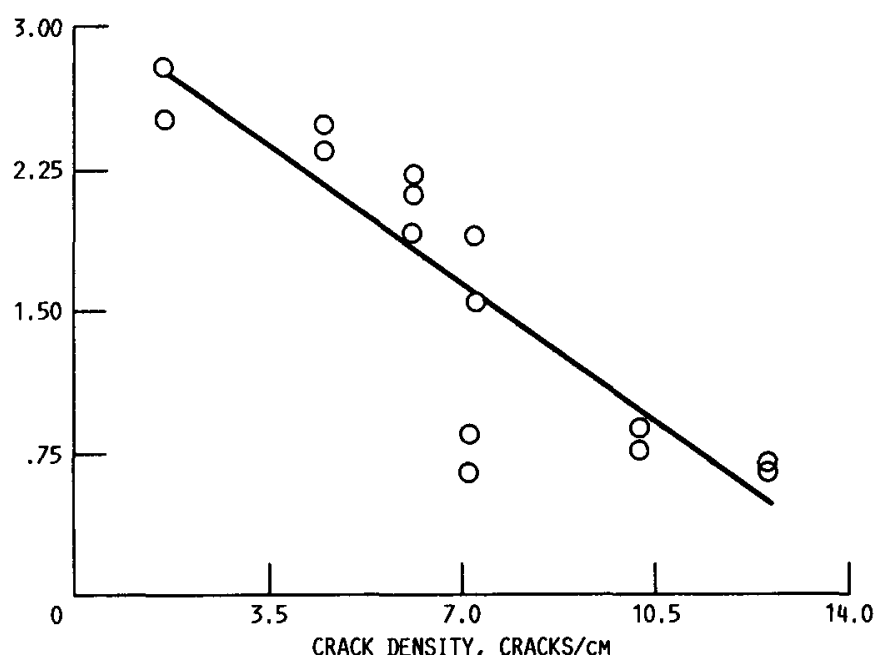

$\begin{array}{ccc}\begin{array}{c}\text { STRESS WAVE } \\ \text { FACTOR } \\ \text { (SWF) }\end{array} & \begin{array}{c}\text { SWF } \\ \text { ERROR, } \\ \text { PERCENT }\end{array} & \begin{array}{c}\text { CRACK } \\ \text { DENSITY, }\end{array} \\ \begin{array}{c}\text { CRACKS/CM } \\ 8.60318 \times 10^{-6}\end{array} & \pm 17.16 & 7.15857 \\ 6.45417 \times 10^{-6} & \pm 15.96 & 7.15857 \\ 8.88935 \times 10^{-6} & \pm 23.50 & 10.2229 \\ 7.75939 \times 10^{-6} & \pm 25.03 & 10.2229 \\ 6.51869 \times 10^{-6} & \pm 20.65 & 12.48 \\ 7.00858 \times 10^{-6} & \pm 20.34 & 12.48 \\ 2.36163 \times 10^{-5} & \pm 14.63 & 4.55286 \\ 2.48667 \times 10^{-5} & \pm 13.26 & 4.55286 \\ 1.93563 \times 10^{-5} & \pm 17.08 & 6.10286 \\ 2.13282 \times 10^{-5} & \pm 15.76 & 6.10286 \\ 2.52091 \times 10^{-5} & \pm 11.17 & 1.58714 \\ 2.78694 \times 10^{-5} & \pm 11.89 & 1.58714 \\ 2.14124 \times 10^{-5} & \pm 14.68 & 6.21 \\ 2.21841 \times 10^{-5} & \pm 12.20 & 6.21 \\ 1.91629 \times 10^{-5} & \pm 23.39 & 7.26714 \\ 1.56148 \times 10^{-5} & \pm 16.50 & 7.26714 \\ { }^{2} \text { CRACK DENSITY } & \text { IS } \pm 0.52 \text { FOR ALL DATA. }\end{array}$

(B) WOVEN FABRIC LAMINATE, LEAST-SQUARES COEFFICIENT R, -0.863 ; INTERCEPT. $3.11719 \times 10^{-5}$; SLOPE, $-2.09510 \times 10^{-6}$.

FIGURE 4. - STRESS WAVE FACTOR (SWF) AS FUNCTION OF CRACK DENSITY FOR CROSS-PLY AND WOVEN FABRIC LAMINATES. 


\begin{tabular}{|c|c|c|c|c|}
\hline \multicolumn{5}{|c|}{ Report Documentation Page } \\
\hline $\begin{array}{l}\text { i. Report No. } \\
\text { NASA TM-100224 }\end{array}$ & \multicolumn{2}{|c|}{ 2. Government Accession No. } & \multicolumn{2}{|c|}{ 3. Recipient's Catalog No. } \\
\hline \multirow{2}{*}{\multicolumn{3}{|c|}{$\begin{array}{l}\text { 4. Title and Subtitle } \\
\text { Transply Crack Density Detection by } \\
\text { Acousto-Uitrasonics }\end{array}$}} & \multicolumn{2}{|l|}{ 5. Report Date } \\
\hline & & & \multicolumn{2}{|c|}{ 6. Performing Organization Code } \\
\hline \multirow{2}{*}{\multicolumn{3}{|c|}{$\begin{array}{l}\text { 7. Author(s) } \\
\text { John H. Hemann, Kenneth J. Bowles, } \\
\text { Harold Kautz, and Paul Cavano }\end{array}$}} & \multicolumn{2}{|c|}{$\begin{array}{l}\text { 8. Performing Organization Report No. } \\
\text { E-3843 }\end{array}$} \\
\hline & & & \multicolumn{2}{|c|}{$\begin{array}{l}\text { 10. Work Unit No. } \\
535-07-01\end{array}$} \\
\hline \multirow{2}{*}{\multicolumn{3}{|c|}{$\begin{array}{l}\text { 9. Pertorming Organization Name and Address } \\
\text { National Aeronautics and Space Administration } \\
\text { Lewis Research Center } \\
\text { Cleveland, Ohio } 44135-3191\end{array}$}} & \multirow{2}{*}{\multicolumn{2}{|c|}{\begin{tabular}{|l|} 
11. Contract or Grant No. \\
13. Type of Report and Period Covered \\
Technical Memorandum
\end{tabular}}} \\
\hline & & & & \\
\hline \multicolumn{3}{|c|}{$\begin{array}{l}\text { 12. Sponsoring Agency Name and Address } \\
\text { National Aeronautics and Space Administration } \\
\text { Washington, D.C. 20546-0001 }\end{array}$} & \multicolumn{2}{|c|}{\begin{tabular}{|l|} 
14. Sponsoring Agency Code \\
\end{tabular}} \\
\hline \multicolumn{5}{|c|}{$\begin{array}{l}\text { 15. Supplementary Noles } \\
\text { Prepared for Acousto-Ultrasonics: Theory and Application, Sponsored by NASA Lewis Research Center, } \\
\text { Blacksburg, Virginia, July 12-15, 1987. John H. Hemann and Paul Cavano, both from Cleveland State } \\
\text { University, Oept. of Civil Engineering, Cleveland, Ohio 44115; Kenneth J. Bowles and Harold Kautz, } \\
\text { NASA Lewis Research Center. }\end{array}$} \\
\hline \multicolumn{5}{|c|}{$\begin{array}{l}\text { 16. Abstract } \\
\text { The acousto-ultrasonic method was applied to a PMR-15 8-harness, satin Celion } \\
3000 \text { fabric composite to determine the extent of transply cracking. A six-ply } \\
0 / 90 \text { laminate was also subjected to mechanical loading, which induced transply } \\
\text { cracking. The stress wave factor (SWF) is defined as the energy contained in the } \\
\text { received signal from a } 2.25-M H z \text { center frequency transducer. The correlation of } \\
\text { the SWF with transply crack density is shown. }\end{array}$} \\
\hline \multicolumn{2}{|c|}{$\begin{array}{l}\text { 17. Key Words (Suggested by Author(s)) } \\
\text { Composites; NDE; Graphite fibers; } \\
\text { Polymer matrices; Microcracking }\end{array}$} & \multicolumn{3}{|c|}{$\begin{array}{l}\text { 18. Distribution Statement } \\
\text { Unclassifled - Unlimited } \\
\text { Subject Category } 24\end{array}$} \\
\hline $\begin{array}{l}\text { 19. Security Classif. (of this rep } \\
\text { Unclass if if }\end{array}$ & 20. Security & iffe) & $\begin{array}{c}\text { 21. No of pages } \\
9\end{array}$ & $\begin{array}{r}\text { 22. Price* } \\
\mathrm{A} 02\end{array}$ \\
\hline
\end{tabular}

